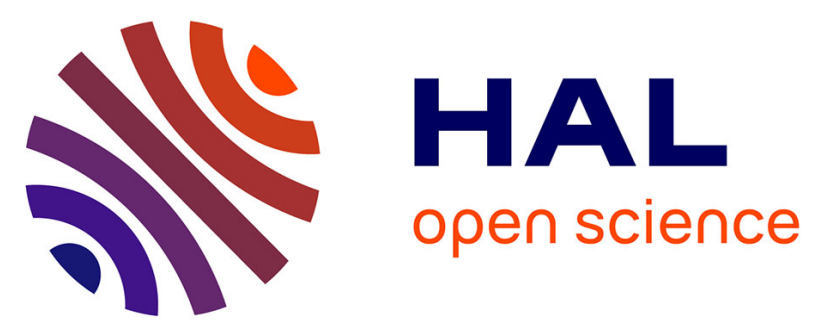

\title{
Coordination-Driven Folding in Multi-Zn II -Porphyrin Arrays Constructed on a Pillar[5]arene Scaffold
}

Thi Minh Nguyet Trinh, Iwona Nierengarten, Haifa Ben aziza, Eric Meichsner,

Michel Holler, Matthieu Chessé, Rym Abidi, Christian Bijani, Yannick

Coppel, Emmanuel Maisonhaute, et al.

\section{To cite this version:}

Thi Minh Nguyet Trinh, Iwona Nierengarten, Haifa Ben aziza, Eric Meichsner, Michel Holler, et al.. Coordination-Driven Folding in Multi-Zn II -Porphyrin Arrays Constructed on a Pillar[5]arene Scaffold. Chemistry - A European Journal, 2017, 23 (46), pp.11011-11021. 10.1002/chem.201701622 . hal-01609037

\section{HAL Id: hal-01609037 \\ https://hal.sorbonne-universite.fr/hal-01609037}

Submitted on 11 Oct 2017

HAL is a multi-disciplinary open access archive for the deposit and dissemination of scientific research documents, whether they are published or not. The documents may come from teaching and research institutions in France or abroad, or from public or private research centers.
L'archive ouverte pluridisciplinaire HAL, est destinée au dépôt et à la diffusion de documents scientifiques de niveau recherche, publiés ou non, émanant des établissements d'enseignement et de recherche français ou étrangers, des laboratoires publics ou privés. 


\title{
Coordination-driven folding in multi-Zn(II)porphyrin arrays constructed on a pillar[5]arene scaffold
}

\author{
Thi Minh Nguyet Trinh, ${ }^{[a]}$ Iwona Nierengarten, ${ }^{[a]}$ Haifa Ben Aziza, ${ }^{[a, b]}$ Eric Meichsner, ${ }^{[a]}$ Michel Holler, ${ }^{[a]}$ \\ Matthieu Chessé,${ }^{[\mathrm{a}]}$ Rym Abidi, ${ }^{[\mathrm{b}]}$ Christian Bijani, ${ }^{[\mathrm{d}]}$ Yannick Coppel, ${ }^{[\mathrm{d}]}$ Emmanuel Maisonhaute, ${ }^{*[\mathrm{c}]}$ \\ Béatrice Delavaux-Nicot, ${ }^{*[d]}$ and Jean-François Nierengarten ${ }^{*[a]}$
}

Dedicated to Prof. Vincenzo Balzani on the occasion of his $80^{\text {th }}$ birthday

\begin{abstract}
Pillar[5]arene derivatives bearing peripheral porphyrin subunits have been efficiently prepared from a decaazide pillar[5]arene building block (17) and Zn(II)-porphyrin derivatives bearing a terminal alkyne function ( 9 and $\mathbf{1 6})$. For the resulting deca$\mathrm{Zn}(\mathrm{II})$-porphyrin arrays (18 and $\mathbf{2 0}$ ), variable temperature NMR studies revealed an intramolecular complexation of the peripheral $\mathrm{Zn}$ (II)-porphyrin moieties by 1,2,3-triazole subunits. As a result, the molecules adopt a folded conformation. This was further confirmed by UV/vis spectroscopy and cyclic voltammetry. In addition, we have also demonstrated that the coordination-driven unfolding of $\mathbf{1 8}$ and 20 can be controlled by an external chemical stimulus. Specifically, addition of an imidazole derivative (22) to solution of $\mathbf{1 8}$ or $\mathbf{2 0}$ breaks the intramolecular coordination at the origin of the folding. The resulting molecular motions triggered by the addition of the imidazole ligand mimics the blooming of a flower.
\end{abstract}

\section{Introduction}

Pillar[5]arene are macrocyclic compounds at the forefront of modern supramolecular chemistry. ${ }^{[1]}$ Whereas their paracyclophane skeleton was already reported in the $80 \mathrm{~s},{ }^{[2]}$ the synthesis of such compounds was difficult thus limiting both their availability and applicability. ${ }^{[2]}$ This problem was solved in 2008 when Ogoshi and co-workers reported an efficient one-step synthesis. In their seminal paper, they have shown that cyclopentameric macrocyclic compounds can be prepared in

[a] Dr. T. M. N. Trinh, Dr. I. Nierengarten, Dr. H. Ben Aziza, E. Meichsner, Dr. M. Holler, M. Chessé, Dr. J.-F. Nierengarten Laboratoire de Chimie des Matériaux Moléculaires, Université de Strasbourg et CNRS (UMR 7509), Ecole Européenne de Chimie, Polymères et Matériaux

25 rue Becquerel, 67087 Strasbourg Cedex 2, France.

E-mail: nierengarten@unistra.fr

[b] Dr. H. Ben Aziza, Prof. R. Abidi

Laboratoire d'Applications de la Chimie aux Ressources et

Substances Naturelles et l'Environnement, Faculté des Sciences de Bizerte, Université de Carthage

7021 Zarzouna Bizerte, Tunisia.

[c] Prof. E. Maisonhaute

Sorbonne Universités, UPMC Univ Paris 06, UMR 8235, Laboratoire

Interfaces et Systèmes Electrochimiques, F-75005 Paris, France.

E-mail: emmanuel.maisonhaute@upmc.fr

[d] C. Bijani, Dr. Y. Coppel, Dr. B. Delavaux-Nicot

Laboratoire de Chimie de Coordination du CNRS, Université de

Toulouse, UPS, INPT,205 route de Narbonne, BP 44099, F-31077

Toulouse Cedex 4, France.

E-mail: beatrice.delavaux-nicot@lcc-toulouse.fr

excellent yields from 1,4-dialkoxybenzene and paraformaldehyde in the presence of $\mathrm{BF}_{3} \cdot \mathrm{Et}_{2} \mathrm{O}^{[3]}$ They also proposed the name pillararene for this class of macrocycles because of their tubular shape. Following this report, the field of pillar[ $n]$ arene has generated significant research efforts focused on both the improvements of their synthetic methods ${ }^{[4]}$ and their incorporation in supramolecular structures. ${ }^{[1]}$ Owing to the presence of ten peripheral substituents, pillar[5]arenes are also attractive compact scaffolds for the preparation of multivalent compounds for biological applications. ${ }^{[5-6]}$ Examples include glycopillar[5]arenes for the specific binding to bacterial lectins ${ }^{[5]}$ and polycationic compounds for gene delivery. ${ }^{[6]}$ On the other hand, nanomaterials with a controlled distribution of functional groups on the macrocyclic framework have been also reported. ${ }^{[7]}$ As part of this research, we now report the preparation of pillar[5]arene derivatives bearing ten peripheral $\mathrm{Zn}(\mathrm{II})$-porphyrin subunits. These compounds have been efficiently prepared from a clickable pillar[5]arene building block and appropriate Zn(II)porphyrin derivatives under copper-catalyzed alkyne-azide cycloaddition (CuAAC) conditions. An unprecedented folding due to intramolecular coordination of the 1,2,3-triazole linkers to the peripheral $\mathrm{Zn}$ (II)-porphyrin moieties has been evidenced for the resulting decatriazoles. Interestingly, this coordination-driven folding can be controlled by an external chemical stimulus, namely addition of an imidazole ligand. As a result, unfolding of the molecules occurs and the resulting molecular motions mimic the blooming of a flower.

\section{Results and Discussion}

Synthesis. The preparation of the first clickable porphyrin building block is depicted in Scheme 1. Treatment of alcohol 1 with $p$-toluenesulfonyl chloride $(p$-TsCl) gave tosylate 2 in $77 \%$ yield. Reaction of $p$-hydroxybenzaldehyde (3) with tosylate 2 under classical Williamson etherification conditions $\left(\mathrm{K}_{2} \mathrm{CO}_{3}\right.$, DMF, $80^{\circ} \mathrm{C}$ ) afforded 4 in $85 \%$ yield. Porphyrin 7 was obtained by using the reaction conditions developed by Lindsey for the synthesis of sterically hindered porphyrins. ${ }^{[8]} \mathrm{A}$ key feature of these conditions involves $\mathrm{BF}_{3}$-ethanol co-catalysis. The condensation of 4 ( 1 equiv.), mesitaldehyde (5, 3 equiv.) and pyrrole (6, 4 equiv.) was performed in $\mathrm{CHCl}_{3}$ (commercial $\mathrm{CHCl}_{3}$ containing $0.75 \%$ ethanol as stabilizer) at room temperature in the presence of $\mathrm{BF}_{3} . \mathrm{Et}_{2} \mathrm{O}$. After $3 \mathrm{~h}$, $p$-chloranil (tetrachlorobenzoquinone) was added to irreversibly convert the porphyrinogen to the porphyrin. Free base porphyrin 7 was subsequently isolated in $15 \%$ yield by tedious chromatographic separations. Metalation of 7 with $\mathrm{Zn}(\mathrm{OAc})_{2}$ gave 8 in $83 \%$ yield. The metalation is conveniently followed by the changes in the absorption spectra. Actually, four bands ( $Q$ bands), responsible for the red-purple color in solution, are observed in the visible region $(515,549,593$ and $648 \mathrm{~nm})$ of the absorption spectrum of free base porphyrin 7. A very sharp and intense band (B band also called Soret band) is also present in the near UV region 
(419 $\mathrm{nm}$ ). Upon metalation, the four $\mathrm{Q}$ bands collapse into two bands $(550$ and $587 \mathrm{~nm})$ due to the higher symmetry of the porphyrin core when metallated ( $D_{4 \mathrm{~h}} v s$. $D_{2 \mathrm{~h}}$ ), but the Soret band $(422 \mathrm{~nm})$ is barely affected. ${ }^{[9]}$ The changes in the visible region result also in a clear color change when going from 7 to 8 . Effectively solutions of free base porphyrin 7 are red-purple while solutions of $\mathrm{Zn}(\mathrm{II})$-porphyrin $\mathbf{8}$ are pink-purple.

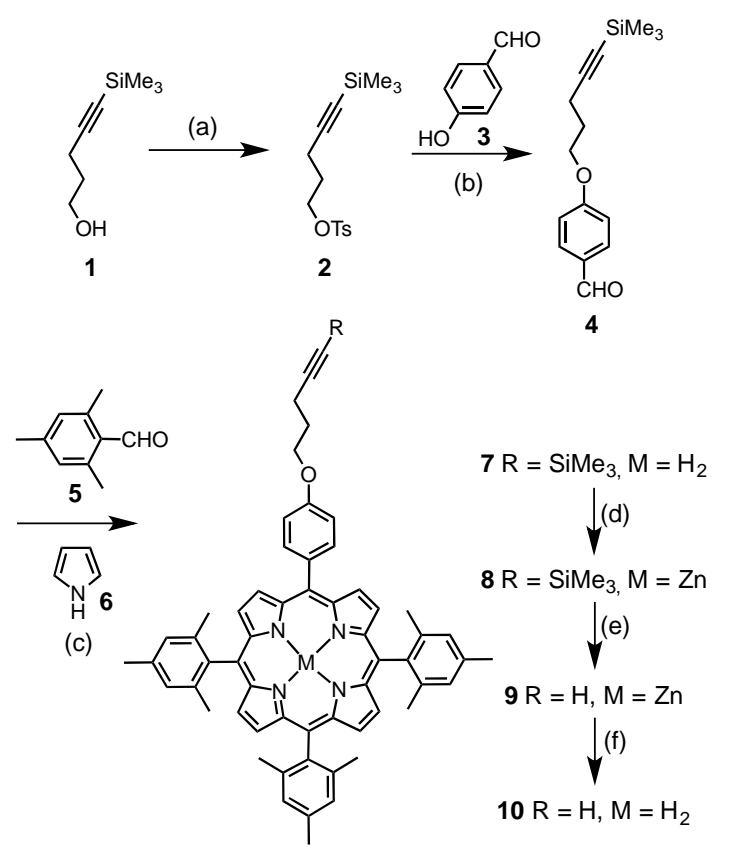

Scheme 1. Reagents and conditions: (a) p-TsCl, pyr, $\mathrm{CH}_{2} \mathrm{Cl}_{2}$, rt $(77 \%)$; (b) $\mathrm{K}_{2} \mathrm{CO}_{3}, \mathrm{DMF}, 80^{\circ} \mathrm{C}(85 \%)$; (c) $\mathrm{BF}_{3} . \mathrm{Et}_{2} \mathrm{O}, \mathrm{CHCl}_{3}$, rt, then chloranil (15\%); (d) $\mathrm{Zn}(\mathrm{OAc})_{2} .2 \mathrm{H}_{2} \mathrm{O}, \mathrm{CHCl}_{3} / \mathrm{MeOH}, \Delta(83 \%)$; (e) TBAF, THF, $0^{\circ} \mathrm{C}(91 \%)$; (f) TFA, $\mathrm{CH}_{2} \mathrm{Cl}_{2}$, rt (96\%).

Reaction of trimethylsilyl (TMS)-protected alkyne 8 with tetra- $n$ butylammonium fluoride (TBAF) in THF afforded $\mathrm{Zn}$ (II)-porphyrin 9 bearing a terminal alkyne function. Inspection of the ${ }^{1} \mathrm{H}$ NMR spectrum of 9 indicates the disappearance of the diagnostic TMS signal observed at $\delta=0.20 \mathrm{ppm}$ for 8 and the concomitant apparition of a triplet $(J=3 \mathrm{~Hz})$ at $\delta=2.04 \mathrm{ppm}$ corresponding to the resonance of the terminal alkyne proton. Moreover, in the IR spectrum of 9, the $\mathrm{C}-\mathrm{H}$ stretching band characteristic of the terminal alkyne function is observed at $3302 \mathrm{~cm}^{-1}$. Finally, $\mathrm{Zn}$ (II)porphyrin 9 was also demetallated by treatment with trifluoroacetic acid (TFA) to afford the corresponding free-base porphyrin (10) that was used as a reference compound for the photophysical studies.

The preparation of a second clickable $\mathrm{Zn}(\mathrm{II})$-porphyrin building block having a slightly longer spacer between the porphyrin core and the terminal alkyne function was also achieved (Scheme 2). Aldehyde $\mathbf{1 1}$ was prepared from 3 and ethyl bromoacetate according to a previously reported method. ${ }^{[10]} A_{3} B$ porphyrin 12 was then obtained in $14 \%$ yield by reaction of 11 ( 1 equiv.) and 5 (3 equiv.) with pyrrole $(6,4$ equiv.) under typical Lindsey conditions. Subsequent treatment with $\mathrm{Zn}(\mathrm{OAc})_{2}$ afforded the corresponding $\mathrm{Zn}(\mathrm{II})$-porphyrin (13) in $99 \%$ yield.

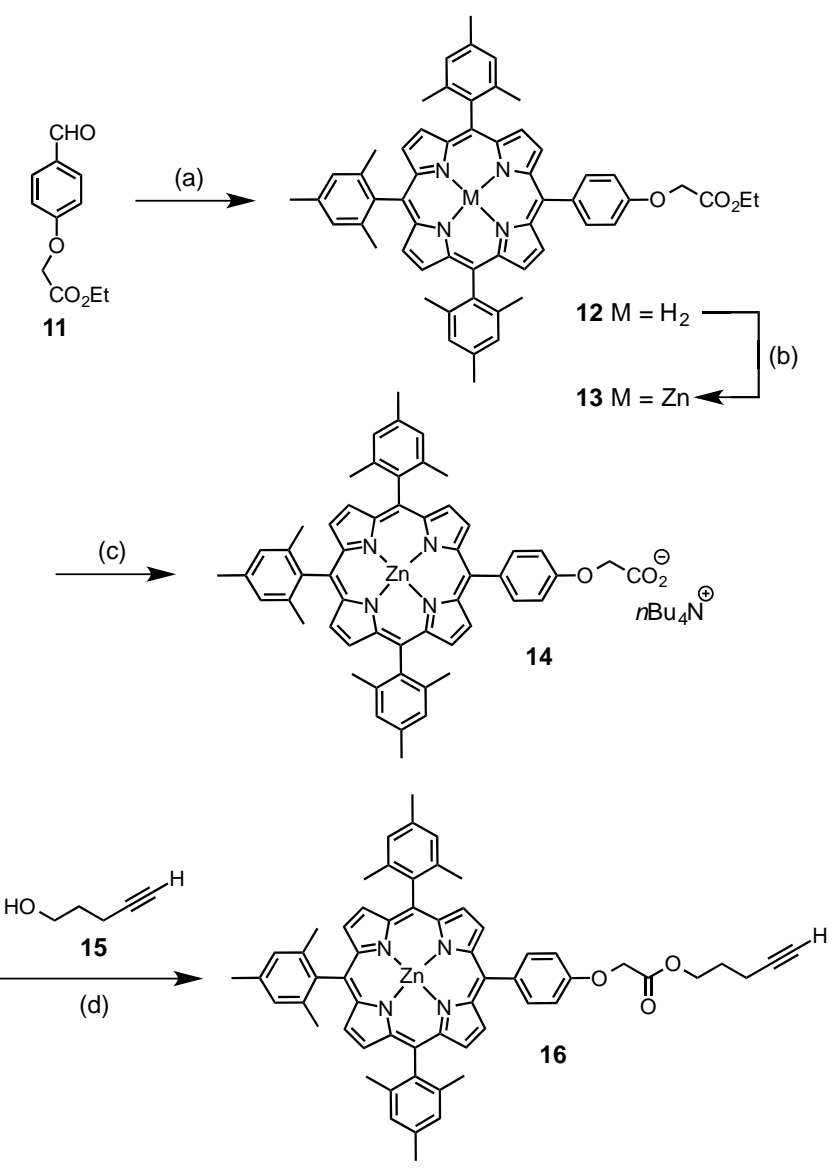

Scheme 2. Reagents and conditions: (a) 5, 6, $\mathrm{BF}_{3} . \mathrm{Et}_{2} \mathrm{O}, \mathrm{CHCl}_{3}$, rt, then chloranil (14\%); (b) $\mathrm{Zn}(\mathrm{OAc})_{2} .2 \mathrm{H}_{2} \mathrm{O}, \mathrm{CHCl}_{3} / \mathrm{MeOH}, \Delta(99 \%) ;$ (c) $\mathrm{K}_{2} \mathrm{CO}_{3}, \mathrm{H}_{2} \mathrm{O}$, THF, $\Delta$ then $n \mathrm{Bu}_{4} \mathrm{NOH}(85 \%)$; (d) DCC, DMAP, $\mathrm{HOBt}, \mathrm{CH}_{2} \mathrm{Cl}_{2}, 0$ to $25^{\circ} \mathrm{C}$ (95\%).

Hydrolysis of the ester function of $\mathbf{1 3}$ was achieved by treatment with $\mathrm{K}_{2} \mathrm{CO}_{3}$ in a mixture THF and water. The resulting carboxylate is poorly soluble in $\mathrm{CH}_{2} \mathrm{Cl}_{2}$ as its potassium salt. In order to obtain a good solubility in organic solvents, tetrabutylammonium hydroxide was added to the reaction mixture and carboxylate $\mathbf{1 4}$ was conveniently extracted with $\mathrm{CH}_{2} \mathrm{Cl}_{2}$ as its tetrabutylammonium salt. Finally, reaction of $\mathbf{1 4}$ with alcohol 15 under esterification conditions using $\mathrm{N}, \mathrm{N}$ dicyclohexylcarbodiimide (DCC), 4-(dimethylamino)pyridine (DMAP) and 1-hydroxybenzotriazole (HOBt) afforded clickable $\mathrm{Zn}(\mathrm{II})$-porphyrin 16 in 95\% yield.

The grafting of the $\mathrm{Zn}(\mathrm{II})$-porphyrin building blocks (9 and 16) onto the pillar[5]arene scaffold was achieved under CuAAC conditions (Scheme 3). Pillar[5]arene building block 17 bearing ten peripheral azide functions was prepared according to a previously reported procedure. ${ }^{[7 a]}$ The reaction of 17 with terminal alkyne 9 was achieved under the typical CuAAC conditions developed for the functionalization of multi-azide cores $^{[11-12]}\left(\mathrm{CuSO}_{4} \cdot 5 \mathrm{H}_{2} \mathrm{O}\right.$, sodium ascorbate, $\left.\mathrm{CH}_{2} \mathrm{Cl}_{2} / \mathrm{H}_{2} \mathrm{O}\right)$. It can be noted that it was difficult to follow the progress of the reaction by simple thin layer chromatography (TLC) analysis. Indeed, IR spectroscopy was a precious complementary tool to indicate the total consumption of the azide residues by monitoring the disappearance of the diagnostic azide band at $2089 \mathrm{~cm}^{-1}$. In this particular case, completion of the reaction was clearly observed after $48 \mathrm{~h}$. After work-up and purification, compound 18 was 
obtained in $96 \%$ yield. The ten peripheral $\mathrm{Zn}(\mathrm{II})$-porphyrin moieties were then demetallated by treatment of 18 with TFA to afford 19.
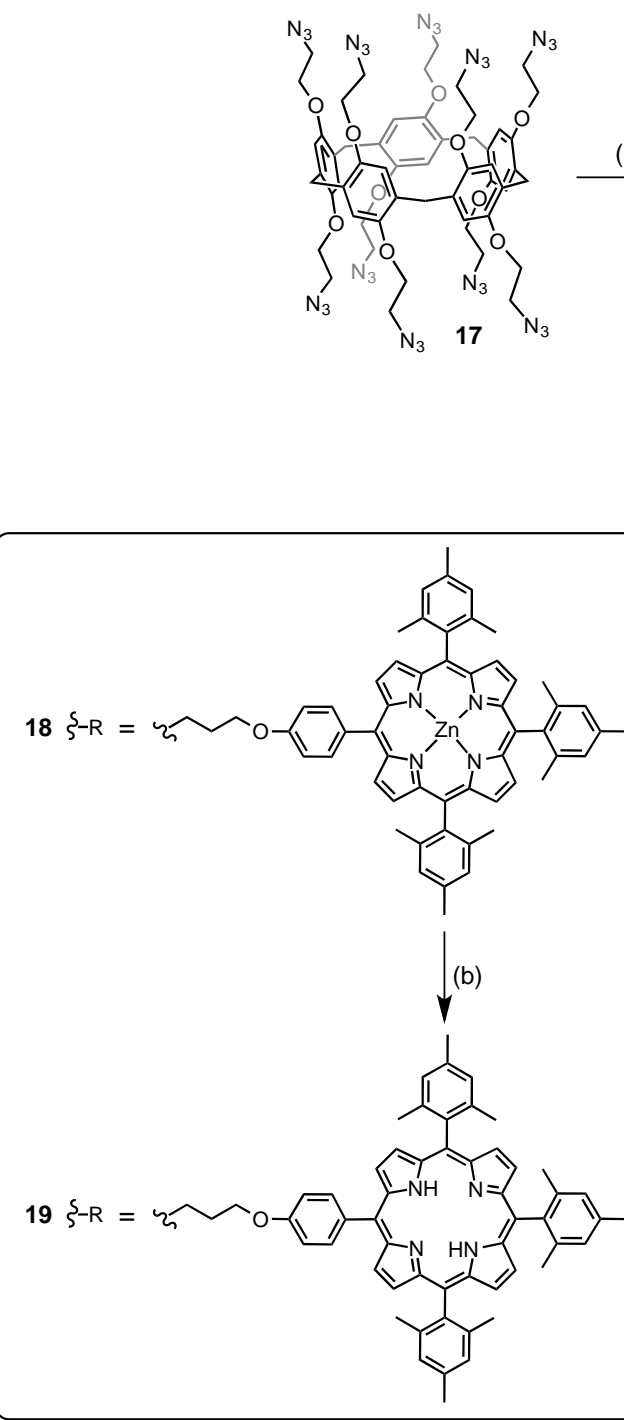

Scheme 3. Preparation of porphyrin-substituted pillar[5]arene derivatives. Reagents and conditions: (a) 9 or 16, $\mathrm{CuSO}_{4} \cdot 5 \mathrm{H}_{2} \mathrm{O}$, sodium ascorbate, $\mathrm{CH}_{2} \mathrm{Cl}_{2}, \mathrm{H}_{2} \mathrm{O}$, 25 ${ }^{\circ} \mathrm{C}$ [from 9: 18 (96\%); from 16: $20(66 \%)$ ]; (b) TFA, $\mathrm{CH}_{2} \mathrm{Cl}_{2}$, rt [from 18: 19 (92\%); from 20: 21 (97\%)].

The reaction conditions used for the preparation of $\mathbf{1 8}$ were then applied to the second clickable Zn(II)-porphyrin derivative (16). A mixture of 17 (1 equiv.), 16 (12 equiv.), $\mathrm{CuSO}_{4} \cdot 5 \mathrm{H}_{2} \mathrm{O}$ ( 0.4 equiv.), sodium ascorbate (0.3 equiv.) in $\mathrm{CH}_{2} \mathrm{Cl}_{2} / \mathrm{H}_{2} \mathrm{O}$ was vigorously stirred at room temperature for 6 days. After work-up and purification by column chromatography on $\mathrm{SiO}_{2}$ followed by gelpermeation chromatography (Biobeads SX-1, $\mathrm{CH}_{2} \mathrm{Cl}_{2}$ ), pillar[5]arene derivative $\mathbf{2 0}$ was obtained in $66 \%$ yield. Finally, treatment of $\mathbf{2 0}$

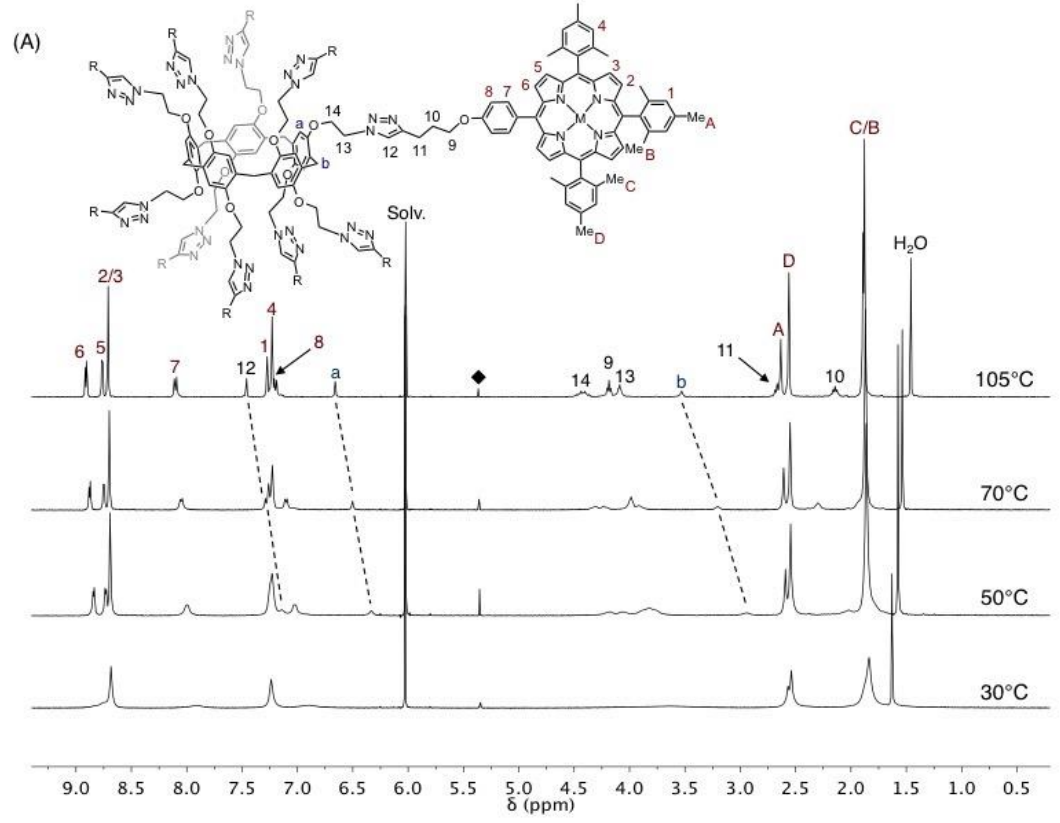

(B)

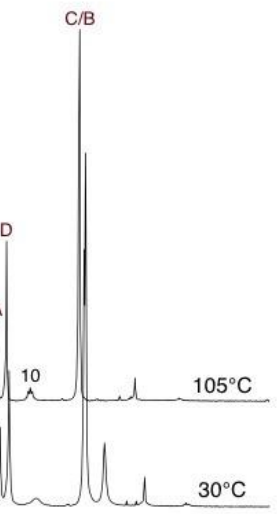


with TFA afforded the corresponding free base prophyrinsubstituted pillar[5]arene derivative (21) in $97 \%$ yield.

\section{Characterization of the porphyrin-substituted pillar[5]arene derivatives.}

Compounds 18-21 were characterized by ${ }^{1} \mathrm{H}$ and ${ }^{13} \mathrm{C}$ NMR, IR and UV/vis spectroscopies. For all the compounds, the proposed structures were also confirmed by MALDI-TOF mass spectrometry. For both free-base porphyrin derivatives (19 and 21), the ${ }^{1} \mathrm{H}$ NMR spectra recorded at room temperature revealed a single set of signals for all the peripheral porphyrin moieties thus showing that they are all equivalent. This is in perfect agreement with the 5 -fold symmetrical structures of compounds 19 and 21. In addition to the signals corresponding to the 10 equivalent peripheral moieties, the resonances arising from the pillar[5]arene core are clearly observed for both 19 and 21 . Actually, the ten aromatic protons of the macrocyclic core are equivalent and give rise to a singlet at $\delta=6.81$ for 19 and 6.69 ppm for 21. Similarly, a singlet is observed for the methylene bridging moieties of the pillar[5]arene core $(\delta=3.45$ and 3.34 ppm for 19 and 21, respectively). Whereas well resolved signals are observed in the ${ }^{1} \mathrm{H}$ NMR spectrum of the free base porphyrin derivatives (19 and 21 ) recorded at room temperature, the spectra of the corresponding $\mathrm{Zn}(\mathrm{II})$-porphyrin analogues (18 and 20) are broad under the same conditions. This is shown in Figure 1A for compound 18. Variable NMR studies revealed however a perfectly reversible narrowing of the signals by increasing the temperature. Indeed, the ${ }^{1} \mathrm{H}$ NMR spectra of 18 and $\mathbf{2 0}$ recorded at high temperature show the expected set of signals (Figures $1 \mathrm{~A}$ and $\mathrm{S} 13 \mathrm{~b}$ ). These observations suggest a fast dynamic exchange between different conformers on the NMR timescale at high temperatures. Importantly the dynamic motions at the origin of the broadening of the spectra of $\mathbf{1 8}$ and 20 at room temperature are specific to the presence of the $\mathrm{Zn}$ (II) centers. Effectively, as shown in Figure 1B, the ${ }^{1} \mathrm{H}$ NMR spectra of free-base porphyrin 19 reveals only minor changes as a function of the temperature.

Figure 1. ${ }^{1} \mathrm{H}$ NMR spectra (400 MHz, $\mathrm{CDCl}_{2} \mathrm{CDCl}_{2}$ ) of compounds $18(\mathrm{~A})$ and 19 (B) recorded at different temperatures $\left(\bullet: \mathrm{CH}_{2} \mathrm{Cl}_{2}\right)$.

In this particular case, limited molecular motions of the peripheral groups at low temperature results in a slight broadening of the signals corresponding to the protons located close to the core moiety of the molecule. At higher temperature, the increased thermal agitation of the peripheral substituents contributes to sharpen these signals $\left(\mathrm{H}_{\mathrm{a}-\mathrm{b}}\right.$ and $\mathrm{H}_{12}$, see Figure 1B). Moreover, agitation also contributes to simplify the pattern observed for the signals of some specific protons. For example, the two $\mathrm{CH}_{2}$ groups of the ethylene linker are both diastereotopic $(\mathrm{H}-13 / 13$ ' and $\mathrm{H}-14 / 14$ ', see Figure 1) and accordingly give rise to four sets of signals at $30^{\circ} \mathrm{C}$. In contrast, only two signals are observed at $105^{\circ} \mathrm{C}$ for the same protons $(\mathrm{H}-13$ and $\mathrm{H}-14$, see Figure $1 \mathrm{~B}$ ) and both methylene subunits appear as enantiotopic under these conditions. As already observed for glycopillar[5]arenes, ${ }^{[5 a]}$ the thermal agitation of the peripheral substituents prevents the transfer of the chiral information between the peripheral subunits and the central core.

In the case of $\mathbf{1 8}$ and $\mathbf{2 0}$, the dramatic changes observed in the ${ }^{1} \mathrm{H}$ NMR spectra as a function of the temperature cannot be simply explained by an increased thermal agitation of the peripheral substituents. The $\mathrm{Zn}$ (II) centers play obviously a key role in the dynamic motions contributing to the broadening of the spectra at low temperature. Actually, the presence of $1,2,3$ triazole moieties in $\mathbf{1 8}$ or $\mathbf{2 0}$ could result in intramolecular interactions with neighboring Zn(II)-porphyrin subunits as schematically depicted in Figure 2. Aromatic compounds with a donating nitrogen moiety are well known ligands of $\mathrm{Zn}$ (II)porphyrins. ${ }^{[13-15]}$ Pyridine and imidazole derivatives are typical examples. Even if 1,2,3-triazoles are weaker ligands owing to their lower basicity, their binding to $\mathrm{Zn}(\mathrm{II})$-porphyrins has been already documented in the literature. ${ }^{[14]}$

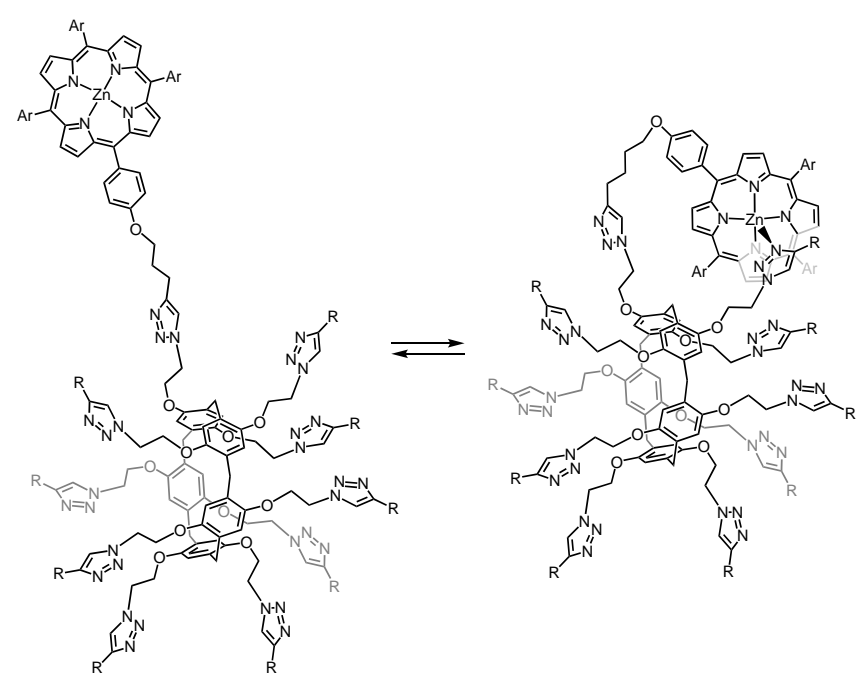

Figure 2. Schematic representation of the dynamic conformational changes resulting from the intramolecular coordination of a 1,2,3-triazole moiety to a $\mathrm{Zn}$ (II)-porphyrin subunit of compound 18.

The binding constant for the intramolecular equilibrium between coordinated and uncoordinated $\mathrm{Zn}(\mathrm{II})$-porphyrins in $\mathbf{1 8}$ is temperature dependent. At high temperature, the dynamic equilibrium is displaced in favor of uncomplexed species and the conformation of $\mathbf{1 8}$ must be similar to that of its analogous freebase analogue (19). Indeed, as shown in Figure 1, the ${ }^{1} \mathrm{H}$ NMR spectra recorded at $105^{\circ} \mathrm{C}$ for $\mathbf{1 8}$ and 19 are very similar. In contrast, at low temperature, association is favored thus generating important conformational changes in 18 . The coordination of the $\mathrm{Zn}$ (II)-porphyrin moieties implies a folding of the molecule and aromatic porphyrin rings are located closer to the core moiety of the molecule. This view is clearly supported by the dramatic shielding observed for the signals of some protons by decreasing the temperature $(\mathrm{H}-\mathrm{a}, \mathrm{H}-\mathrm{b}$ and $\mathrm{H}-12$, see Figure $1 \mathrm{~A})$. Indeed, these chemical shift changes result from the ring current effect of the aromatic porphyrin moieties that are spatially close to $\mathrm{H}-\mathrm{a}, \mathrm{H}-\mathrm{b}$ or $\mathrm{H}-12$ when intramolecular coordination of $\mathrm{Zn}(\mathrm{II})$ centers with 1,2,3-triazole groups occurs. ${ }^{1} \mathrm{H}$ NMR spectra of $\mathbf{1 8}$ were also recorded a low temperature (from room temperature to $-70^{\circ} \mathrm{C}$ ). A continuous broadening was observed thus showing that the coordination/decoordination process remains faster than the NMR timescale even at $-70^{\circ} \mathrm{C}$ and/or that compound $\mathbf{1 8}$ does not adopt a preferential folded conformation at $-70^{\circ} \mathrm{C}$. A similar behavior has been also observed for compound $\mathbf{2 0}$ with longer spacer subunits. In both cases, this interpretation was further supported by the selfdiffusion coefficients (D) of compounds 18-21 deduced from 
DOSY experiments (see Table S1). Comparison of the free-base porphyrin derivatives with their $\mathrm{Zn}(\mathrm{II})$ coordinated analogues revealed an increase in their $D$ value $(13( \pm 5) \%$ for 19 and $9( \pm 6) \%$ for 21$)$ corresponding to a respective volume reduction of $32( \pm 12) \%$ (18 vs. 19) and $22( \pm 15) \%$ (20 vs. 21). These observations showing a reduced average volume for the $\mathrm{Zn}(\mathrm{II})$ porphyrin derivatives is fully consistent with a dynamic intramolecular coordination process leading to a folded conformation.

The occurrence of intramolecular interactions of 1,2,3triazole groups with neighboring $\mathrm{Zn}(\mathrm{II})$-porphyrin subunits in $\mathbf{1 8}$ and $\mathbf{2 0}$ was also supported by their absorption spectra recorded in $\mathrm{CH}_{2} \mathrm{Cl}_{2}$ at room temperature (Figures 3, $\mathrm{S} 11 \mathrm{~g}$ and $\mathrm{S} 13 \mathrm{~g}$ ).
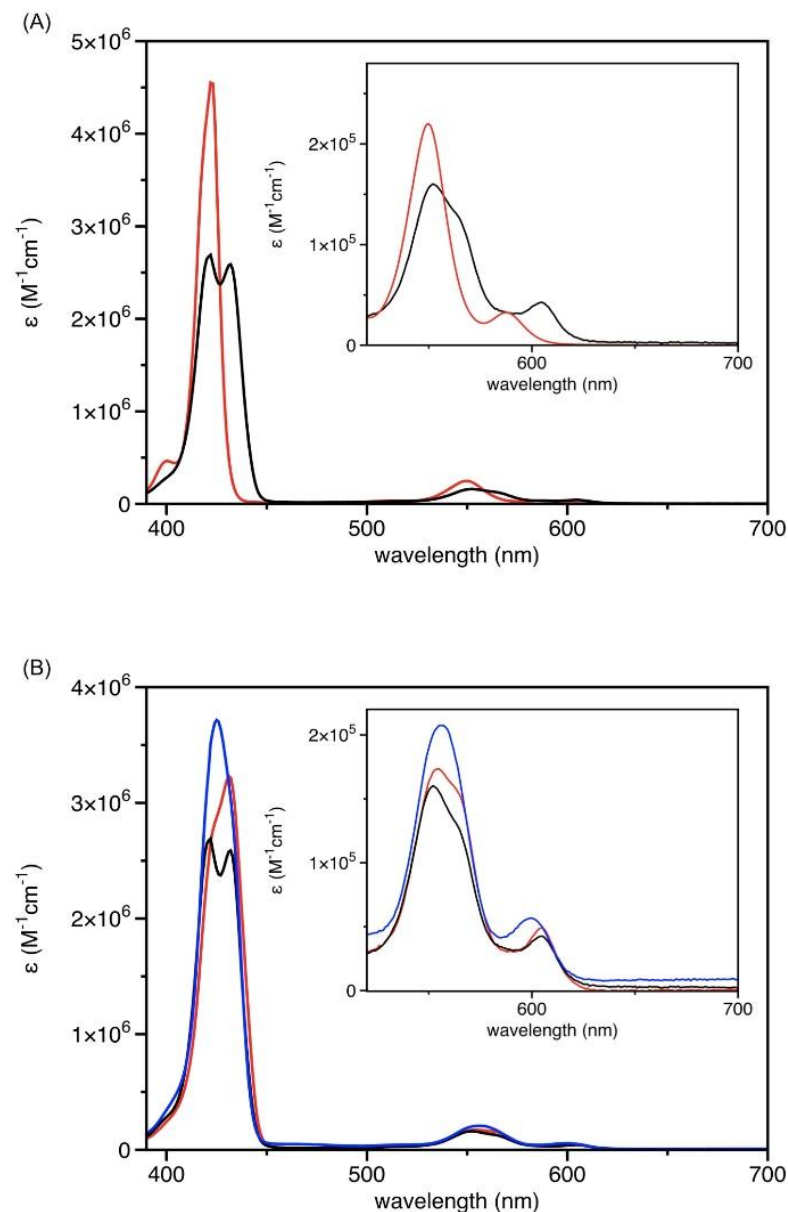

Figure 3. (A) Absorption spectra of compounds 18 (black) and 9 (red) recorded in $\mathrm{CH}_{2} \mathrm{Cl}_{2}$ at $25^{\circ} \mathrm{C}$. (B) Absorption spectra of compounds 18 recorded in different solvents at $25^{\circ} \mathrm{C}$ (blue: $\mathrm{CHCl}_{3}$, black: $\mathrm{CH}_{2} \mathrm{Cl}_{2}$, red: toluene).

In both cases, the absorption bands of the $\mathrm{Zn}(\mathrm{II})$-porphyrin moieties are effectively broadened and red-shifted when compared to those of appropriate model compounds. This is a clear signature ${ }^{[13-15]}$ for the apical coordination of $\mathrm{Zn}(\mathrm{II})$-porphyrin moieties in 18 and 20 by a nitrogen ligand. Moreover, no evidence of molecular aggregation (e.g. intermolecular coordination) could be detected within the range of concentrations used for the optical measurements $\left(10^{-5}\right.$ to $10^{-7}$ M) as the absorbance follows the Beer-Lambert law for both 18 and 20. Therefore, the apical coordination of the $\mathrm{Zn}(\mathrm{II})$-porphyrin moieties by 1,2,3-triazoles in $\mathbf{1 8}$ and $\mathbf{2 0}$ occurs in an intramolecular manner. It can be also noted that the shape of the absorption spectra of both $\mathbf{1 8}$ and $\mathbf{2 0}$ is significantly affected by the nature of the solvent as shown in Figure 3B for dichloromethane, chloroform and toluene. Close inspection of the shape of the Soret band suggests a higher degree of association in the less polar solvent (toluene). In this solvent, the red-shifted absorption maxima of the Soret band that is typical for coordinated Zn(II)-porpyrins becomes effectively more pronounced. This observation is consistent with the solventdependence of the binding constant $\left(K_{\mathrm{A}}\right)$ reported in the literature for complexes resulting from the intermolecular association of $\mathrm{N}$-ligands and $\mathrm{Zn}$ (II)-porphyrin derivatives. ${ }^{[14]}$ The $K_{\mathrm{A}}$ values are in general higher in less polar solvents.

The absorption spectra of the free-base porphyrinsubstituted pillar[5]arene derivatives $\mathbf{1 9}$ and $\mathbf{2 1}$ are depicted in Figures 4. In contrast to what was observed for their $\mathrm{Zn}$ (II) analogues, the absorption spectra of $\mathbf{1 9}$ and $\mathbf{2 1}$ are only very slightly broadened when compared to model free-base porphyrin 10. Indeed, their absorption spectra corresponds well to the sum of their constitutive subunits $(10 \times 10)$ thus showing rather limited electronic interactions (if any) among the free-base porphyrin moieties in $\mathbf{1 9}$ and $\mathbf{2 1 .}$

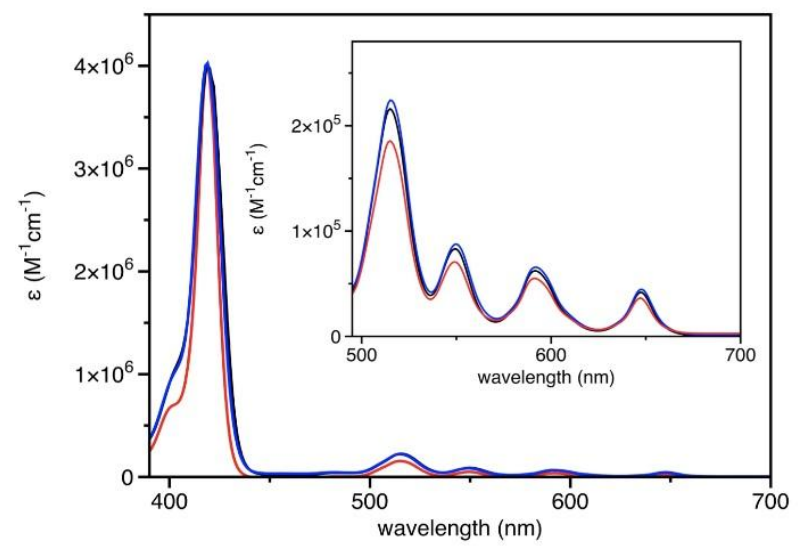

Figure 4. Absorption spectra of compounds 19 (blue), 21 (black) and 10 (red) recorded in $\mathrm{CH}_{2} \mathrm{Cl}_{2}$ at $25^{\circ} \mathrm{C}$.

These observations further support our interpretation of the UV/vis data of the $\mathrm{Zn}(\mathrm{II})$ analogues 18 and 20 . The splitting of the Soret band and the overall broadening of the absorption spectra observed for $\mathbf{1 8}$ and $\mathbf{2 0}$ are not related to electronic interactions between their peripheral porphyrin subunits but result from an intramolecular coordination-driven conformational folding of the molecules. Indeed, the molecular motions resulting from the coordination/decoordination phenomena observed for compounds 18 and 20 mimic the blooming of a flower. As deduced from the variable temperature NMR studies, the folded conformation is favored at low temperature. By increasing the temperature, the intramolecular coordination is disfavored and the molecules adopt an open conformation like a flower that bloom.

Blooming of the molecular flowers with a chemical stimulus (input). In order to gain more control on the conformational changes observed for $\mathbf{1 8}$ and $\mathbf{2 0}$, we became interested in using an external input to trigger the blooming of molecular flowers 18 
and 20. For this purpose, 1-phenylimidazole (22) was selected as an external chemical input. Indeed, compound $\mathbf{2 2}$ is a stronger ligand for $\mathrm{Zn}(\mathrm{II})$-porphyrins ${ }^{[13-15]}$ when compared to 1,2,3-triazoles and one may anticipate that a preferential coordination of the $\mathrm{Zn}(\mathrm{II})$-porphyrin groups in $\mathbf{1 8}$ or $\mathbf{2 0}$ will occur in the presence of an excess of 22. As shown in Figure 5, dramatic changes were evidenced in the UV/vis spectrum of $\mathbf{2 0}$ upon addition of an excess of imidazole derivative 22 (14 equiv.).

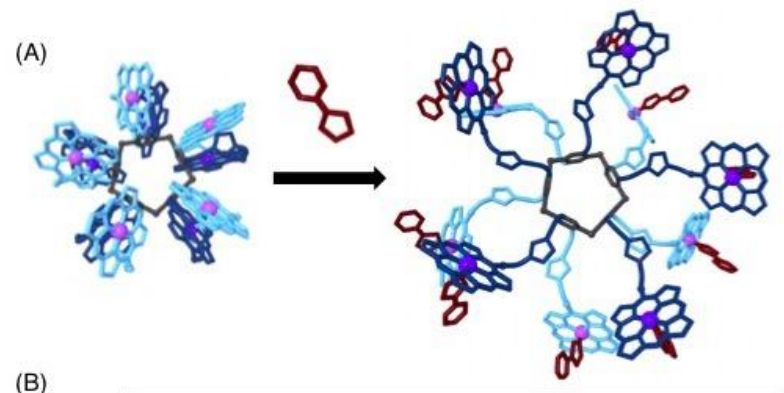

(B)

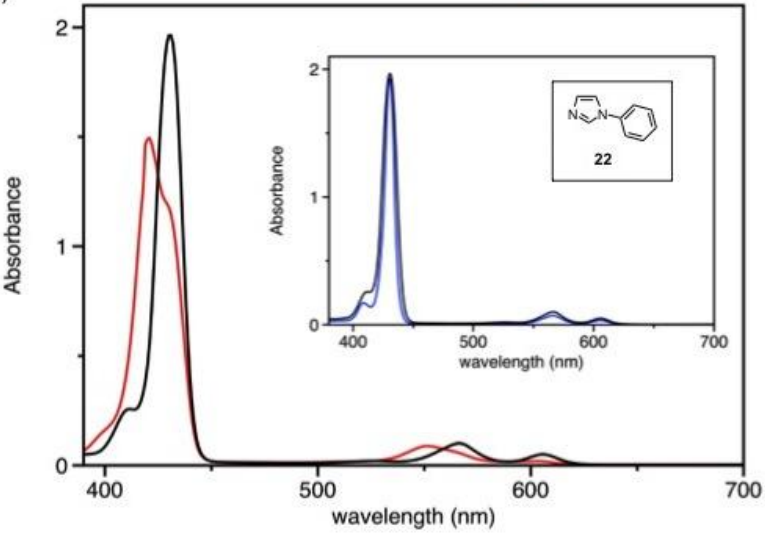

Figure 5. (A) Schematic representation of the blooming of molecular flower 20 upon addition of 1-phenylimidazole (22). (B) Absorption spectra of compound 20 before (red) and after (black) addition of 14 equiv. of $22\left(\mathrm{CH}_{2} \mathrm{Cl}_{2}, 25^{\circ} \mathrm{C}\right.$, [20] $=0.48 \square \mathrm{M}$ ); inset: comparison of the absorption spectra of pillar[5]arene 20 (black) and model porphyrin 16 (blue) in the presence of 14 equiv. of 22 $\left(\mathrm{CH}_{2} \mathrm{Cl}_{2}, 25^{\circ} \mathrm{C},[20]=0.48 \square \mathrm{M},[16]=3.6 \square \mathrm{M}\right)$.

The Soret band is red-shifted and becomes narrow. A similar effect is also observed for the $Q$ bands. These are diagnostic signatures for an effective apical coordination of $\mathbf{2 2}$ onto the $\mathrm{Zn}$ (II)-porphyrin subunits of $\mathbf{2 0}$. Importantly, the absorption spectrum of $\mathbf{2 0}$ upon addition of $\mathbf{2 2}$ corresponds well to the one recorded for model porphyrin $\mathbf{1 6}$ in the presence of imidazole $\mathbf{2 2}$ (Figure 5B, inset) thus suggesting that the intramolecular coordination of $\mathrm{Zn}$ (II)-porphyrin moieties by 1,2,3-triazole subunits is not effective anymore. Coordination of the $\mathrm{Zn}(\mathrm{II})$ porphyrins of compound 20 by imidazole ligand 22 is thus capable of preventing the coordination-induced folding in the multi-Zn(II)-porphyrin array. As schematically shown in Figure $5 \mathrm{~A}$, addition of ligand $\mathbf{2 2}$ to $\mathbf{2 0}$ allows for a complete unfolding of the compound thus mimicking the blooming of a flower.

In order to further evidence this blooming event upon addition of imidazole 22, ${ }^{1} \mathrm{H}$ NMR binding studies were also carried out. For both 18 and 20, dramatic changes were observed in the ${ }^{1} \mathrm{H}$ NMR spectra recorded after addition of imidazole 22. This is shown in Figure 6 for compound 18.

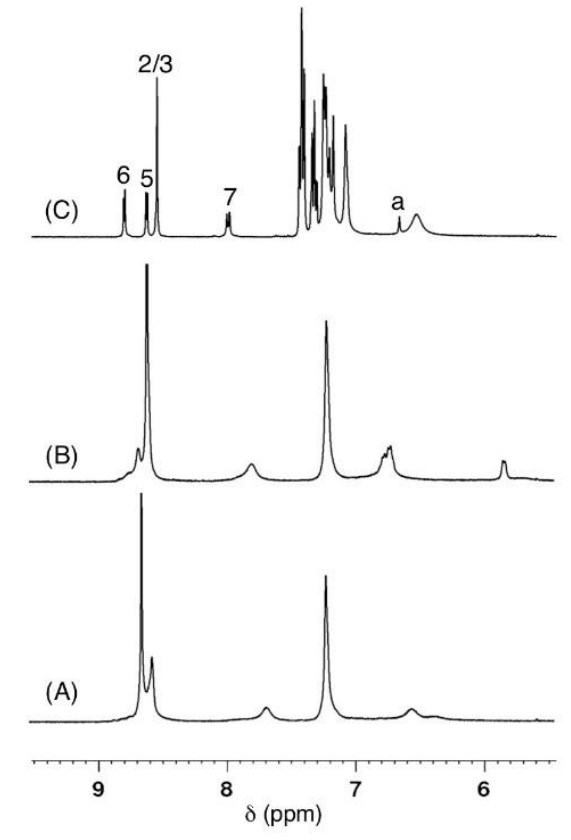

Figure 6. Aromatic region of the ${ }^{1} \mathrm{H}$ NMR spectra of pillar[5]arene 18 (400 $\mathrm{MHz}, \mathrm{CD}_{2} \mathrm{Cl}_{2}, 25^{\circ} \mathrm{C}$ ) recorded before (A) and after addition of $5(\mathrm{~B})$, and $45(\mathrm{C})$ equivalents of imidazole 22 (for the numbering, see Fig. 1).

The broad signals of the pillar[5]arene derivative are sharpened by adding increasing amount of ligand 22. This clearly shows that the dynamic folding at the origin of the broadening of the ${ }^{1} \mathrm{H}$ NMR spectrum of $\mathbf{1 8}$ is progressively prevented by coordination of imidazole ligands 22 to the $\mathrm{Zn}(\mathrm{II})$ centers of $\mathbf{1 8}$. In other words, the intermolecular coordination of 22 to the $\mathrm{Zn}(\mathrm{II})$ porphyrin subunits of $\mathbf{1 8}$ is strong enough to prevent the intramolecular coordination of the 1,2,3-triazole moieties in the multiporphyrin array. As a result, addition of an excess of 22 promotes the blooming of molecular flower 18. A similar behavior was also evidenced for derivative 20 (Figure S16b). In both cases, the blooming event was also supported by DOSY experiments. Effectively, significant changes in the $D$ values were observed upon addition of ligand 22 to $\mathrm{CD}_{2} \mathrm{Cl}_{2}$ solutions of 18 and 20 (see Table S2). In the presence of an excess of ligand 22, the $D$ values were decreased by $13.0( \pm 5) \quad(18)$ and $14.0( \pm 6) \%(20)$. These changes in $D$ values correspond to a coordination-induced volume expansion of $46( \pm 12)$ (18) and $49( \pm 15) \%(20)$. Interestingly, the $D$ values deduced for 18 and 20 in the presence of an excess of $22(2.2( \pm 0.1)$ and $2.1( \pm 0.1) x$ $10^{-10} \mathrm{~m}^{2} . \mathrm{s}^{-1}$ respectively) are very similar to those recorded for the corresponding free-base porphyrin derivatives 19 and 21 $\left(2.2( \pm 0.1)\right.$ and $2.2( \pm 0.1) \times 10^{-10} \mathrm{~m}^{2} . \mathrm{s}^{-1}$, respectively) thus providing good evidence for similar unfolded structures.

Electrochemical properties. The electrochemical properties of pillar[5]arenes 18-21 were determined by cyclic voltammetry (CV) and Osteryoung Square Wave Voltammetry (OSWV). ${ }^{[16]}$ For the sake of comparison, electrochemical measurements have been also carried out with model $\mathrm{Zn}$ (II)-porphyrin derivatives 9 and 16. All the experiments were performed at room temperature in $\mathrm{CH}_{2} \mathrm{Cl}_{2}$ solutions containing tetra $n$ butylammonium tetrafluoroborate $(0.10 \mathrm{M})$ as supporting electrolyte and ferrocene $(\mathrm{Fc})$ as internal reference, with a $\mathrm{Pt}$ wire as the working electrode and a saturated calomel electrode 
(SCE) as a reference. Potential data for all of the compounds are collected in Table 1.

Table 1. Electrochemical data of compounds 9, 16 and 18-21 determined by OSWV on a Pt working electrode in $\mathrm{CH}_{2} \mathrm{Cl}_{2}+0.1 \mathrm{M} n$ - $\mathrm{Bu}_{4} \mathrm{NBF}_{4}$ at room temperature. Ferrocene is used as internal reference. ${ }^{[a, b]}$

\begin{tabular}{|c|c|c|c|c|c|c|c|}
\hline & $E_{3}^{o x}$ & $E_{2}^{o x}$ & $E_{1}^{o x}$ & $E_{1}^{\text {Red }}$ & $E_{2}^{\text {Red }}$ & $E_{3}^{\text {Red }}$ & $E_{4}^{\text {Red }}$ \\
\hline 19 & & +1.66 & +1.06 & -1.23 & -1.60 & - & \\
\hline 21 & & +1.70 & +1.06 & -1.24 & -1.60 & & \\
\hline 9 & & +1.18 & +0.85 & -1.40 & -1.61 & -1.82 & \\
\hline 16 & & +1.18 & +0.85 & -1.41 & -1.83 & & \\
\hline 18 & +1.29 & +0.92 & +0.73 & -1.41 & -1.59 & 1.88 & \\
\hline 20 & +1.24 & +0.89 & +0.72 & -1.43 & -1.54 & -1.65 & -1.94 \\
\hline
\end{tabular}

OSWVs were obtained using a sweep width of $20 \mathrm{mV}$, a frequency of $20 \mathrm{~Hz}$ and a step potential of $5 \mathrm{mV}$. [b] Potential values in oxidation $\left(E_{\mathrm{ox}}\right)$ and in reduction $\left(E_{\text {red }}\right)$ in Volt vs. SCE $\left(\mathrm{Fc}^{+} / \mathrm{Fc}\right.$ is observed at $0.55 \mathrm{~V} \pm 0.01 \mathrm{~V}$ vs. SCE).

Free-base porphyrin-substituted pillar[5]arenes 19 and 21 display the diagnostic electrochemical signature of $\mathrm{H}_{2}$-porphyrin derivatives. ${ }^{[17]}$ The first one-electron transfer is reversible both in oxidation and in reduction, while the second one is at most only partially reversible as deduced from their CVs (see ESI). The redox potentials are similar for both compounds thus indicating that the length of the spacer has no significant influence on their electrochemical properties. Moreover the observed electrochemical processes are due to the simultaneous oxidation or reduction of ten independent free-porphyrin units in a similar environment. As reported for dendrimers bearing multiple peripheral redox centers, this indicates that electrostatic interactions between porphyrinic cations or anions are shielded by the supporting electrolyte. ${ }^{[18]}$

The typical electrochemical features of $\mathrm{Zn}(\mathrm{II})$-porphyrin systems are clearly observed for model compounds 9 and 16. When compared to 19 and 21, all the redox processes are cathodically shifted. In contrast, the electrochemical behavior of multi- $\mathrm{Zn}(\mathrm{II})$ porphyrin arrays 18 and 20 is significantly different (see ESI). As a typical example, the CVs recorded for pillar[5]arene $\mathbf{2 0}$ and the corresponding model compound (16) are depicted in Figure 7.

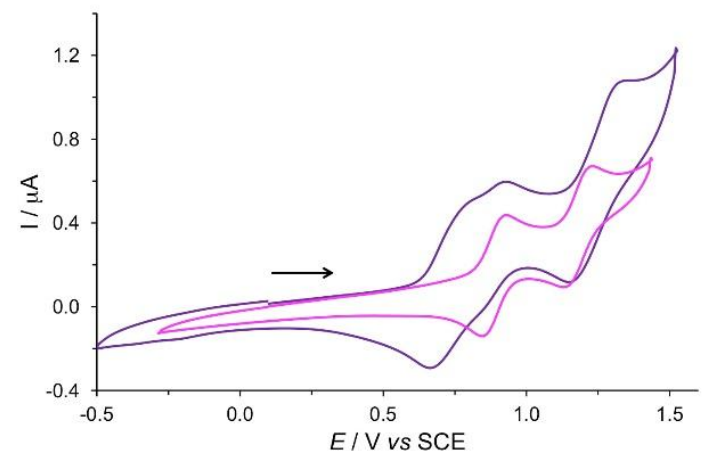

Figure 7. Cyclic voltammograms of compounds $\mathbf{1 6}$ (pink) and $\mathbf{2 0}$ (purple) on a $\mathrm{Pt}$ electrode in $\mathrm{CH}_{2} \mathrm{Cl}_{2}+0.1 \mathrm{M}\left[n \mathrm{Bu}_{4} \mathrm{~N}\right]\left[\mathrm{BF}_{4}\right]$ at a scan rate of $200 \mathrm{mV} \mathrm{s}^{-1}$ (toward anodic potentials).
Three characteristic oxidation waves are clearly detected for compounds 18 and 20 in OSWVs and CVs. The first one $\left(E_{10 x}\right)$ is cathodically shifted when compared to model Zn(II)-porphyrins 9 and $16\left(E_{1}{ }^{\mathrm{ox}}\right)$, while the second one observed around $0.90 \mathrm{~V}$ $\left(E_{2}{ }^{\mathrm{ox}}\right)$ is rather close to the oxidation potentials of the model compounds. The third one $\left(E_{3}{ }^{\text {ox }}\right)$ conversely is slightly anodically shifted. Similarly, the reduction of compounds $\mathbf{1 8}$ and $\mathbf{2 0}$ also involves an additional process when compared to the corresponding model Zn(II)-porphyrins (see ESI). In light of the NMR and UV-Vis spectroscopic data, it is believed that the origin of the supplementary oxidation and reduction processes observed for $\mathbf{1 8}$ and $\mathbf{2 0}$ must be related to the existence of intramolecular 1,2,3-triazole-porphyrin interactions in these compounds. Indeed, these interacting $\mathrm{Zn}(\mathrm{II})$-porphyrin units are more electron-rich and should be at the same time easier to oxidize and more difficult to reduce. In order to confirm this hypothesis, further electrochemical investigations were carried out in the presence of imidazole ligand 22. The OSWVs recorded for model compound $\mathbf{1 6}$ in the presence of $\mathbf{2 2}$ are shown in Figure 8A (anodic scan, for the cathodic scan, see the ESI). Upon addition of 1 equiv. of imidazole 22, the oxidation waves of both coordinated and uncoordinated $\mathrm{Zn}$ (II)-porphyrins are simultaneously observed. Saturation is reached upon addition of 2 equiv. and only the electrochemical signature of $[(\mathbf{1 6})(\mathbf{2 2})]$ is then detected. When compared to 16, the first oxidation wave is cathodically shifted in $[(16)(22)]$ while the second one is anodically shifted. This indicates that the radical cation of the $\mathrm{Zn}$-porphyrin is stabilized upon complexation by $\mathbf{2 2}$. In contrast, while the potential of the first reduction wave is significantly affected by the presence of $\mathbf{2 2}$, the second reduction is always observed at the same redox potential. This latter observation suggests a decoordination of 22 upon the first reduction.

(A)

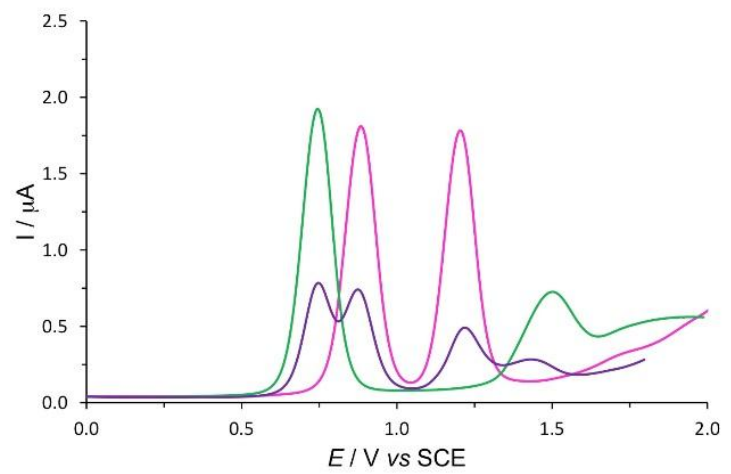


(B)

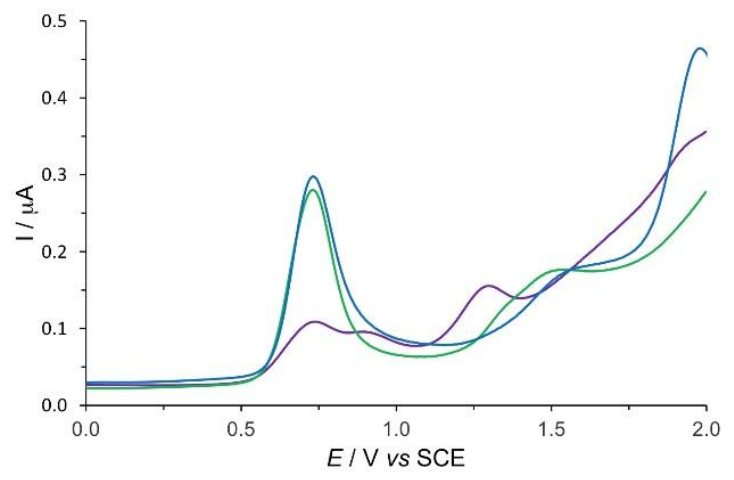

Figure 8. (A) OSWVs (anodic scan) of compound 16 before (pink) and after successive additions of 22 [1 (purple) and 2 (green) equiv.] and (B) compound 18 before (purple) and after successive additions of 22 [5 equiv. (green) and 10 equiv. (blue)] on a $\mathrm{Pt}$ electrode in $\mathrm{CH}_{2} \mathrm{Cl}_{2}+0.1 \mathrm{M}\left[n \mathrm{Bu}_{4} \mathrm{~N}\right]\left[\mathrm{BF}_{4}\right]$ at room temperature (frequency $20 \mathrm{~Hz}$, amplitude $20 \mathrm{mV}$, step potential $5 \mathrm{mV}$ ).

All these observations nicely confirm that the peculiar electrochemical behavior observed for the multiporphyrinic arrays 18 and 20 results effectively from the partial intramolecular coordination of $\mathrm{Zn}(\mathrm{II})$-porphyrin moieties with 1,2,3-triazoles. In both cases, the relative intensity of the two first oxidation waves shows that at least 5 out of the 10 porphyrins are complexed by a triazole unit under these conditions $\left(\mathrm{CH}_{2} \mathrm{Cl}_{2}\right.$, room temperature), but not all of them. We also noticed that for both $\mathbf{1 8}$ and $\mathbf{2 0}$, the ratio between the two first oxidation peaks is unchanged while switching the scan rate between 0.1 and $1 \mathrm{Vs}^{-1}$. This indicates that the dynamic interconversion process between coordinated and uncoordinated porphyrins does not occur within the voltammetric timescale. ${ }^{[19]}$ Moreover, as decoordination seems to occur upon the first reduction, an electrochemical input appears thus capable of triggering the blooming of molecular flowers 18 and 20. This hypothesis is further reinforced by the only partial reversibility of the first reduction wave of $\mathbf{1 8}$ and $\mathbf{2 0}$ in agreement with a square scheme mechanism. ${ }^{[20]}$

Finally, CVs and OSWVs of compound 18 and 20 were also recorded in the presence of imidazole 22. As a typical example, the OSWVs recorded for $\mathbf{1 8}$ upon addition of $\mathbf{2 2}$ are depicted in Figure $8 \mathrm{~B}$. The addition of ligand $\mathbf{2 2}$ to polytopic receptor $\mathbf{1 8}$ is responsible for a simplification of the voltammogram and only the typical electrochemical signature of coordinated $\mathrm{Zn}$ (II)porphyrin subunits is observed. The observed electrochemical processes are now arising from the simultaneous oxidation of the ten independent peripheral porphyrin moieties that are all in a similar state. We also notice that only 5 equiv. are necessary to switch ensure a total coordination of the ten porphyrin units, in agreement with the CVs of $\mathbf{1 8}$ and $\mathbf{2 0}$ without 22.

\section{Conclusions}

Pillar[5]arene derivatives bearing peripheral porphyrin subunits have been efficiently prepared from a clickable pillar[5]arene building block (17) and $\mathrm{Zn}(\mathrm{II})$-porphyrin derivatives bearing a terminal alkyne function ( 9 and 16$)$. The characterization of the resulting deca-Zn(II)-porphyrin arrays (18 and 20) has been complicated owing to an intramolecular complexation of the peripheral $\mathrm{Zn}$ (II)-porphyrin moieties by 1,2,3-triazole subunits. As a result of this intramolecular coordination, the ${ }^{1} \mathrm{H}$ NMR spectra of $\mathbf{1 8}$ and $\mathbf{2 0}$ are broad at room temperature. Variable temperature NMR studies have shown that the conformational equilibrium resulting from the coordination-driven molecular folding is dynamic and well-resolved ${ }^{1} \mathrm{H}$ NMR spectra have been recorded at high temperature. Actually, the thermodynamic equilibrium is displaced in favor of uncoordinated species at high temperature and molecules $\mathbf{1 8}$ and $\mathbf{2 0}$ adopt an open conformation similar to the one of their free-base porphyrin analogues (19 and 21) under these conditions. In contrast, coordination of the $\mathrm{Zn}$ (II)-porphyrin moieties by 1,2,3-triazole groups is favored at low temperature and thus the molecules adopt a folded conformation. Finally, we have shown that the coordination-driven folding of $\mathbf{1 8}$ and $\mathbf{2 0}$ can be controlled by an external chemical stimulus. Specifically, addition of an imidazole derivative (22) to solution of $\mathbf{1 8}$ or $\mathbf{2 0}$ prevents the intramolecular coordination at the origin of the folding. As a result, unfolding of molecules $\mathbf{1 8}$ and $\mathbf{2 0}$ occurs. This view is further supported by a variation of the diffusion coefficient as measured by DOSY and by the electrochemical signature. The resulting molecular motions triggered by the addition of the imidazole ligand mimics the blooming of a flower.

\section{Experimental Section}

Synthesis.

The preparation and characterization (Figures S1-14) of all the new compounds are described in the ESI.

\section{Electrochemistry.}

The electrochemical properties of compounds 9, 16, 18-21 were determined by cyclic voltammetry (CV) and Osteryoung Square Wave Voltammetry (OSWV) (See experimental selected curves in SI).The cyclic voltammetric measurements were carried out with a potentiostat Autolab PGSTAT100. Experiments were performed at room temperature in a homemade airtight three-electrode cell connected to a vacuum/argon line. The reference electrode consisted of a saturated calomel electrode (SCE) separated from the solution by a bridge compartment. The counter electrode was a platinum wire of ca. $1 \mathrm{~cm}^{2}$ apparent surface. The working electrode was a $\mathrm{Pt}$ microdisk $(0.5 \mathrm{~mm}$ diameter $)$. The supporting electrolyte $\left[\mathrm{nBu}_{4} \mathrm{~N}\right]\left[\mathrm{BF}_{4}\right]$ (Fluka, $99 \%$ electrochemical grade) was used as received and simply degassed under argon. Dichloromethane was freshly distilled over $\mathrm{CaH}_{2}$ prior to use. The solutions used during the electrochemical studies were typically $2 \times 10^{-4}$ or $3 \times 10^{-3} \mathrm{M}$ in compound and $0.1 \mathrm{M}$ in supporting electrolyte. Before each measurement, the solutions were degassed by bubbling $\mathrm{Ar}$ and the working electrode was polished with a polishing machine (Presi P230). Under these experimental conditions, $\mathrm{Fc}+\mathrm{Fc}$ is observed at $+0.55 \pm 0.01 \mathrm{~V}$ vs. SCE. OSWVs were obtained using an amplitude of $20 \mathrm{mV}$, a frequency of 20 $\mathrm{Hz}$, and a step potential of $5 \mathrm{mV}$. For addition experiments on 16 and 18 , a $\mathrm{CH}_{2} \mathrm{Cl}_{2}$ solution of $0.5 \mathrm{~mL}$ of compound 22 was prepared under argon, and the adjusted volume was syringed into the stirred electrochemical mixture under argon atmosphere.

\section{Acknowledgements}

Financial support by the International Center for Frontier Research in Chemistry, the LabEx "Chimie des Systèmes Complexes", the CNRS and the University of Strasbourg is gratefully acknowledged. TMNT thanks 
the University of Strasbourg (IdEx 2013) and HBA the Tunisian Ministry of Higher Education and Scientific Research and Technology for their fellowships. We thank Dr. A. Saquet (LCC) for electrochemical measurements, Drs. M. Schmitt and E. Wasielewski (UMR 7509) for high-field NMR measurements and Dr. J.-M. Strub (ECPM) for the mass spectra. We further thank Drs. R. Caballero and M. Vartanian for the initial preparation of compound 16 .

\section{Keywords: Pillararene $\bullet$ Porphyrin $\bullet$ CuAAC $\cdot$ Molecular} machine $\cdot$ Molecular folding

[1] For reviews on pillar[n]arenes, see: (a) P. J. Cragg, K. Sharma, Chem Soc. Rev. 2012, 41, 597-607. (b) M. Xue, Y. Yang, X. Chi, Z. Zhang, F. Huang, Acc. Chem. Res. 2012, 45, 1294-1308. (c) T. Ogoshi, J. Incl. Phenom. Macrocycl. Chem. 2012, 72, 247-262. (d) T. Ogoshi, T.-a. Yamagishi, Eur. J. Org. Chem. 2013, 2961-2975. (e) D. Cao, H. Meier, Asian J. Org. Chem. 2014, 3, 244-262. (f) T. Ogoshi, T. Yamagishi, Chem. Commun. 2014, 50, 4776-4787. (g) N. L. Strutt, H. Zhang, S. T. Schneebeli, J. F. Stoddart, Acc. Chem. Res. 2014, 47, 2631-2642. (h) K. Yang, Y. Pei, Z. Pei, Chem. Commun. 2016, 52, 9316-9326. (i) T. Ogoshi, T.-a. Yamagishi, Y. Nakamoto, Chem. Rev. 2016, 116, 79378002. (j) T. Kakuta, T. Yamagashi, T. Ogoshi, Chem. Commun. 2017 DOI: 10.1039/C7CC01833A.

[2] G. W. Gribble, C. F. Nutaitis, Tetrahedron Lett. 1985, 26, 6023-6026.

[3] T. Ogoshi, S. Kanai, S. Fujinami, T.-a. Yamagishi, Y. Nakamoto, J. Am. Chem. Soc. 2008, 130, 5022-5023.

[4] (a) T. Ogoshi, T. Aoki, K. Kitajima, S. Fujinami, T.-a. Yamagishi, Y. Nakamoto, J. Org. Chem. 2011, 76, 328-331. (b) D. Cao, Y. Kou, J. Liang, Z. Chen, L. Wang, H. Meier, Angew. Chem. Int. Ed. 2009, 48, 9721-9723. (c) Y. Kou, H. Tao, D. Cao, Z. Fu, D. Schollmeyer, H. Meier, Eur. J. Org. Chem. 2010, 6464-6470. (d) Y. Ma, Z. Zhang, X. Ji, C. Han, J. He, Z. Abliz, W. Chen, F. Huang, Eur. J. Org. Chem. 2011 5331-5335. (e) T. Boinski, A. Szumma, Tetrahedron 2012, 68, 9419 9422. (f) M. Holler, N. Allenbach, J. Sonet, J.-F. Nierengarten, Chem. Commun. 2012, 48, 2576-2578.

[5] (a) I. Nierengarten, K. Buffet, M. Holler, S. P. Vincent, J.-F. Nierengarten, Tetrahedron Lett. 2013, 54, 2398-2402. (b) G. Yu, Y. Ma, C. Han, Y. Yao, G. Tang, Z. Mao, C. Gao, F. Huang, J. Am. Chem. Soc. 2013, 135, 10310-10313. (c) K. Buffet, I. Nierengarten, N Galanos, E. Gillon, M. Holler, A. Imberty, S. E. Matthews, S. Vidal, S. P. Vincent, J.-F. Nierengarten, Chem. Eur. J. 2016, 22, 2955-2963. (d) S. P. Vincent, K. Buffet, I. Nierengarten, A. Imberty, J.-F. Nierengarten Chem. Eur. J. 2016, 22, 88-92. (e) N. Galanos, E. Gillon, A. Imberty, S. E. Matthews, S. Vidal, Org. Biomol. Chem. 2016, 14, 3476-3481.

[6] (a) I. Nierengarten, M. Nothisen, D. Sigwalt, T. Biellmann, M. Holler, J. S. Remy, J.-F. Nierengarten, Chem. Eur. J. 2013, 19, 17552-17558. (b) K. Yang, Y. Chang, J. Wen, Y. Lu, Y. Pei, S. Cao, F. Wang, Z. Pei, Chem. Mater. 2016, 28, 1990-1993.

[7] (a) I. Nierengarten, S. Guerra, M. Holler, J.-F. Nierengarten, R. Deschenaux, Chem. Commun. 2012, 48, 8072-8074. (b) I. Nierengarten, S. Guerra, M. Holler, L. Karmazin-Brelot, J. Barbera, R. Deschenaux, J.-F. Nierengarten, Eur. J. Org. Chem. 2013, 3675-3684. (c) S. Pan, M. Ni, B. Mu, Q. Li, X.-Y. Hu, C. Lin, D. Chen, L. Wang, Adv. Funct. Mater. 2015, 25, 3571-3580. (d) I. Nierengarten, S. Guerra, H. Ben Aziza, M. Holler, R. Abidi, J. Barberá, R. Deschenaux, J.-F. Nierengarten, Chem. Eur. J. 2016, 22, 6185-6189.

[8] (a) B. J. Littler, Y. Ciringh, J. S. Lindsey, J. Org. Chem. 1999, 64, 28642872. (b) G. R. Geier III, B. J. Littler, J. S. Lindsey, J. Chem. Soc Perkin Trans. 2 2001, 701-711. (c) R. W. Wagner, D. S. Lawrence, J.
S. Lindsey, Tetrahedron Lett. 1987, 28, 3069-3070. (d) J. S. Lindsey, R. W. Wagner, J. Org. Chem. 1989, 54, 828-836.

[9] (a) X. Huang, K. Nakanishi, N. Berova, Chirality 2000, 12, 237-255. (b) T. Hashimoto, Y.-C. Choe, H. Nakano, K. Hirao, J. Phys. Chem. A 1999, 103, 1894-1904. (c) M. Gouterman, J. Chem. Phys. 1959, 30, 1139-1161.

[10] J. Bhaumik, Z. Yao, K. Eszter Borbas, M. Taniguchi, J. S. Lindsey, J. Org. Chem. 2006, 71, 8807-8817

[11] H. C. Kolb, M. G. Finn, K. B. Sharpless, Angew. Chem. Int. Ed. 2001 40, 2004-2021.

[12] (a) I. Nierengarten, J.-F. Nierengarten, Chem. Rec. 2015, 15, 31-51. (b) I. Nierengarten, J.-F. Nierengarten, Chem Asian J. 2014, 9, 1436-1444.

[13] A. Matea-Alonso, C. Sooambar, M. Prato, C. R. Chimie 2006, 9, 944951 and references therein.

[14] (a) N. T. Nguyen, G. M. Mamardashvili, O. M. Kulikova, I. G. Scheblykin, N. Z. Mamardashvili, W. Dehaen, RSC Adv. 2014, 4, 19703-19709. (b) C. Maeda, P. Kim, S. Cho, J. K. Park, J. M. Lim, D. Kim, J. Vura-Weis, M. R. Wasielewski, H. Shinokubo, A. Osuka, Chem Eur. J. 2010, 16, 5052-5061. (c) C. Maeda, S. Yamaguchi, C. Ikeda, H. Shinokubo, A. Osuka, Org. Lett. 2008, 10, 549-552. (d) J.-P. Collin, F. Durola, V. Heitz, F. Reviriego, J.-P. Sauvage, Y. Trolez, Angew. Chem. Int. Ed. 2010, 49, 10172-10175.

[15] (a) N. Armaroli, F. Diederich, L. Echegoyen, T. Habicher, L. Flamigni, G. Marconi, J.-F. Nierengarten, New J. Chem. 1999, 23, 77-83. (b) W. S. Li, K. S. Kim, D.-L. Jiang, H. Tanaka, T. Kawai, J. H. Kwon, D. Kim, T. Aida, J. Am. Chem. Soc. 2006, 128, 10527-10532. (c) K. Yoosaf, J. lehl, I. Nierengarten, M. Hmadeh, A.-M. Albrecht-Gary, J.-F. Nierengarten, N. Armaroli, Chem. Eur. J. 2014, 20, 223-231.

[16] R. G. Compton, C. E. Banks, Understanding Voltammetry, Imperial College Press, London, 2011.

[17] (a) K.M. Kadish, L.R. Shiue, R.K. Rhodes, L.A. Bottomley, Inorg. Chem. 1981, 20, 1274-1277. (b) K.M. Kadish, R.K. Rhodes, Inorg. Chem 1981, 20, 2961-2966. (c) C.-L. Lin, M.-Y. Fang, S.-H. Cheng, J. Electroanal. Chem. 2002, 531, 155-162. (d) F. D'Souza, P.M. Smith, L. Rogers, M.E. Zandler, E. Melvin, D.-M. S. Islam, Y. Araki, O. Ito, Inorg Chem. 2006, 45, 5057-5065. (e) C.-Y. Huang, C.-Y. Hsu, L.-Y. Yang, C.-J. Lee, T.-F. Yang, C.-C. Hsu, K., C.-H. Ke, Y. O. Su, Eur. J. Inorg. Chem. 2012, 1038-1047. (f) H. C. Cheng, P. P.Y. Chen, Su, Y. O., Dalton Trans. 2014, 43, 1424-1433.

[18] (a) C. Amatore, Y. Bouret, E. Maisonhaute, J. I. Goldsmith, H. D. Abruna, ChemPhysChem. 2001, 2, 130-134. (b) C. Amatore, Y. Bouret, E. Maisonhaute, J. I. Goldsmith, H. D. Abruna, Chem. Eur. J. 2001, 7, 2206-2226. (c) C. Amatore, F. Grun, E. Maisonhaute, Angew. Chem. Int. Ed. 2003, 42, 4944-4947. (d) J. A. Camerano, M. A. Casado, U. Hahn, J. F. Nierengarten, E. Maisonhaute, C. Amatore, New J. Chem. 2007, 31, 1395-1399. (e) U. Hahn, E. Maisonhaute, C. Amatore, J. F. Nierengarten, Angew. Chem. Int. Ed. 2007, 46, 951-954. (f) P. Fortgang, E. Maisonhaute, C. Amatore, B. Delavaux-Nicot, J. lehl, J. F. Nierengarten, Angew. Chem. Int. Ed. 2011, 50, 2364-2367. (g) P. Fortgang, M. Urbani, M. Holler, J.-F. Nierengarten, A. Moreau, B. Delavaux-Nicot, E. Maisonhaute, Electroanalysis 2015, 27, 1010-1016. (h) X. S. Zhou, B. W. Mao, C. Amatore, R. G. Compton, J. L. Marignier, M. Mostafavi, J. F. Nierengarten, E. Maisonhaute, Chem. Commun. 2016, 52, 251-263.

[19] J.-M. Saveant, Elements Molecular and Biomolecular Electrochemistry, John Wiley and Son, Hoboken, New Jersey, 2006.

[20] C. Amatore, D. Genovese, E. Maisonhaute, N. Raouafi, B. Schöllhorn, Angew. Chem. Int. Ed. 2008, 47, 5211-5214. 


\section{Entry for the Table of Contents}

\section{FULL PAPER}

Molecular flowers. Deca-Zn(II)porphyrin arrays constructed on a pillar[5]arene scaffold adopt a folded conformation due to intramolecular complexation of the $\mathrm{Zn}$ (II)-porphyrin moieties by 1,2,3-triazole subunits. An external chemical stimulus can trigger the unfolding of these compounds thus mimicking the blooming of a flower.
Thi Minh Nguyet Trinh, Iwona Nierengarten, Haifa Ben Aziza, Eric Meichsner, Michel Holler, Matthieu Chessé, Rym Abidi, Christian Bijani, Yannick Coppel, Emmanuel Maisonhaute, * Béatrice Delavaux-Nicot, * and Jean-François Nierengarten*

Coordination-driven folding in multi$\mathrm{Zn}$ (II)porphyrin arrays constructed on a pillar[5]arene scaffold 